\title{
Influence of sleep bruxism on primary headaches in children: a 2013-2018 literature review
}

Wpływ bruksizmu w czasie snu na powstawanie pierwotnych bólów głowy u dzieci przegląd literatury z lat 2013-2018

\author{
1 Department of Sports Medicine, Medical University of Lublin, Lublin, Poland \\ ${ }^{2}$ Department of Rehabilitation and Physiotherapy, Medical University of Lublin, Lublin, Poland \\ ${ }^{3}$ Department of Functional Masticatory Disorders, Medical University of Lublin, Lublin, Poland \\ Correspondence: Michał Ginszzt, Chodźki 7, 20-093 Lublin, Poland, tel.: +48 602533 723, e-mail: michalginszt@umlub.pl
}

\begin{abstract}
Introduction: Headaches are a common problem in children and adolescents and are the primary cause of school absence. Primary headaches are the most common type of headaches in children (migraine, tension-type headaches, neuralgia), which may be the consequence of bruxism, a parafunction consisting in teeth clenching during sleep and when awake. The aim of this review was to determine the link between bruxism episodes and primary headaches in children. Material and methods: The material for this review were studies found independently by two authors in the PubMed, ResearchGate and Google Scholar academic research databases. In order to identify suitable papers the search was conducted using the combination of the following keywords: "bruxism," "children," "headache" (according to Medical Subject Headings). Two studies were included in this review. Results: Children with diagnosed episodes of bruxism had a higher risk of primary headache. Sleep bruxism was more frequently diagnosed in children who had episodes of migraine. However, according to the assessment criteria adopted in this review, the results of the analysed studies were rated as "moderate value of evidence." Conclusions: Considering the value of evidence and the size of study groups in the analysed research projects, a link between bruxism and primary headaches in children cannot be confirmed. Further research is necessary regarding the relationship between bruxism and primary headaches in children.
\end{abstract}

Keywords: bruxism, children, headaches

Wprowadzenie: Bóle głowy są częstym problemem u dzieci i młodzieży i stanowią główną przyczynę absencji szkolnej. U dzieci występują najczęściej pierwotne bóle głowy (migrena, napięciowe bóle głowy, neuralgia), które mogą być następstwem parafunkcji w postaci bruksizmu - zaciskania zębów w czasie snu i w okresie czuwania. Celem niniejszego przeglądu było określenie związku pomiędzy występowaniem epizodów bruksizmu i pierwotnych bólów głowy u dzieci. Materiał i metoda: Materiał do niniejszego przeglądu stanowiły prace wyszukane w bazach publikacji naukowych PubMed, ResearchGate i Google Scholar niezależnie przez dwóch autorów. W celu identyfikacji odpowiednich opracowań wyszukiwanie zostało przeprowadzone przy użyciu kombinacji słów kluczowych: bruxism, children, headache (według Medical Subject Headings). Do niniejszego przeglądu zostały zakwalifikowane dwie prace badawcze. Wyniki: Dzieci, u których zdiagnozowano epizody bruksizmu, cechowały się większym ryzykiem wystąpienia pierwotnego bólu głowy. Bruksizm senny był zaś częściej stwierdzany u dzieci, u których występowały epizody migrenowych bólów głowy. Jednak według kryteriów oceny przyjętych w tym przeglądzie wyniki analizowanych prac zostały ocenione jako „umiarkowana wartość dowodów”. Wnioski: Biorąc pod uwagę wartość dowodów naukowych oraz wielkość badanych grup w analizowanych pracach badawczych, nie można potwierdzić związku pomiędzy bruksizmem a pierwotnymi bólami głowy u dzieci. Konieczne są dalsze badania dotyczące zależności występowania bruksizmu i pierwotnych bólów głowy u dzieci.

Słowa kluczowe: bruksizm, dzieci, bóle głowy 


\section{INTRODUCTION}

$\mathrm{M}$ asticatory parafunctions are defined as abnormal, persistent masticatory activities deviating from the norm in terms of quality and quantity. Bruxism is a parafunction with the most serious health consequences ${ }^{(1)}$. It involves repetitive masticatory muscle activity characterised by teeth clenching and grinding. There are two forms of bruxism: sleep bruxism (SB) and awake bruxism $(\mathrm{AB})$. In sleep bruxism, the person affected is not aware of the condition, which can lead to abnormal tooth wear, excessive tension in masticatory muscles and development of temporomandibular joint dysfunction ${ }^{(2)}$. Current research reports suggest that sleep bruxism could also lead to primary headaches ${ }^{(3)}$.

Headaches are a common health problem in children and adolescents and are the primary cause of school absence ${ }^{(4)}$. The rate of recurrent and severe attacks of headache gradually increases with age, from $4.5 \%$ in children aged $4-6$ years to $27.4 \%$ among teenagers aged $16-18$ years (in the population of the United States) ${ }^{(5)}$. The rate of headache in boys and girls before 12 years of age is the same (slightly less than 10\%). After the age of 12 there is a significant increase in the frequency of headaches in girls (36\%) compared to boys $(20 \%)^{(5,6)}$. The majority of headaches in children and adolescents are primary headaches ${ }^{(7)}$. The International Headache Society (IHS) considers primary headaches to include migraine, tension-type headaches and neuralgia, among others ${ }^{(8)}$.

The aim of this review was to determine the link between bruxism episodes and primary headaches in children based on recent literature from 2013-2018.

\section{MATERIAL AND METHODS}

The material for this review included studies found independently by two authors in the PubMed, ResearchGate and Google Scholar academic research databases. In order to identify suitable papers the search was conducted using the combination of the following keywords: "bruxism," "children," "headache" (in accordance with Medical Subject Headings - MeSH). At the first stage of the review, publications from 2013-2018 were found based on their titles. The second stage involved reviewing full texts of papers and their abstracts. Based on the considerations above two papers were included in this review (Tab. 1).

The analysed studies were assessed based on the questions presented in Tab. 2. The questions for scoring were based on the quality assessment tool for diagnostic accuracy studies (QUADAS) recommended by Cochrane Collaboration, an independent international organisation working for evidence-based medicine. The material for the review and the results of the analysed studies were assessed according to QUADAS recommendations, which is presented in Tabs. 2 and 3.

\section{RESULTS}

Children with diagnosed episodes of bruxism had a higher risk of primary headache ${ }^{(9)}$ (Tab. 1). Sleep bruxism was more frequently diagnosed in children who had episodes of migraine ${ }^{(10)}$ (Tab. 1). However, according to the assessment criteria adopted in this review, the results of the analysed studies were rated as "moderate value of evidence" (Tabs. 2, 3).

\section{DISCUSSION}

The aim of this review was to determine the link between bruxism episodes and primary headaches in children. In both analysed studies, a link between episodes of bruxism and the occurrence of primary headaches was found. The results obtained by both Bortoletto et al. ${ }^{(9)}$ and Masuko et al. ${ }^{(10)}$ are consistent with the study by van der Meer et al. ${ }^{(11)}$ in which a central mechanism was claimed to exist that links functional masticatory disorders, including bruxism, with primary headaches. According to van der Meer et al., the disorders in question should not be treated separately, but rather globally, in order to standardise and streamline the diagnostic and therapeutic process ${ }^{(11)}$.

\begin{tabular}{|l|l|l|l|}
\hline $\begin{array}{l}\text { Author, title, } \\
\text { year of publication }\end{array}$ & Aim of the study, material and methods & Results & Conclusions \\
\hline $\begin{array}{l}\text { Bortoletto et al., } \\
\text { The relationship between } \\
\text { bruxism, sleep quality, and } \\
\text { headaches in schoolchildren, } \\
2017\end{array}$ & $\begin{array}{l}\text { Aim of the study: to assess the relationship between sleep bruxism and } \\
\text { headache in schoolchildren. } \\
\text { Material and methods: } 103 \text { children aged 3-6 years (49 were } \\
\text { diagnosed with bruxism). Sleep bruxism was diagnosed based on parental } \\
\text { observations of teeth clenching/grinding and incisor/oclusal wear, } \\
\text { in accordance with the American Academy of Sleep Medicine criteria. } \\
\text { Sleep quality was assessed using a questionnaire describing the child's } \\
\text { sleep characteristics. }\end{array}$ & $\begin{array}{l}\text { Sleep bruxism was } \\
\text { diagnosed in 49 children } \\
\text { (47.6\%). Individuals } \\
\text { with sleep bruxism had } \\
\text { a 3.25 times higher risk } \\
\text { of headache. }\end{array}$ & $\begin{array}{l}\text { Children with diagnosed sleep } \\
\text { bruxism had a higher risk } \\
\text { of primary headache. Headache } \\
\text { was associated only with sleep } \\
\text { bruxism, while awake bruxism } \\
\text { did not correlate with primary } \\
\text { headache }\end{array}$ \\
\hline $\begin{array}{l}\text { Masuko et al., Prevalence } \\
\text { of bruxism in children } \\
\text { with episodic migraine - } \\
\text { a case-control study with } \\
\text { polysomnography, 2014 }\end{array}$ & $\begin{array}{l}\text { Aim of the study: to investigate the rate of sleep bruxism in children } \\
\text { with episodic migraine compared to the control group using } \\
\text { polysomnography. } \\
\text { Material and methods: control group: 20 individuals aged 6-12 } \\
\text { without headache; study group: 20 patients with episodic migraine. } \\
\text { Bruxism was assessed using the American Academy of Sleep Medicine } \\
\text { criteria. Polysomnography was conducted in both groups. }\end{array}$ & $\begin{array}{l}\text { Five children with episodic } \\
\text { migraine (25\%) displayed } \\
\text { sleep bruxism, while no } \\
\text { individual from the control } \\
\text { group was found to have } \\
\text { this problem (p=0.045). }\end{array}$ & $\begin{array}{l}\text { Sleep bruxism is more frequently } \\
\text { diagnosed in children with } \\
\text { episodic migraine }\end{array}$ \\
\hline
\end{tabular}

Tab. 1. Analysed studies 


\begin{tabular}{|c|c|c|}
\hline \multicolumn{3}{|c|}{ Questions and scores } \\
\hline Q1 & Size of study group & $\begin{array}{l}0-9-0 \text { pts } \\
10-99-1 \text { pt } \\
\geq 100-2 \text { pts }\end{array}$ \\
\hline Q2 & $\begin{array}{l}\text { Presence of control } \\
\text { group }\end{array}$ & $\begin{array}{l}\text { None }-0 \text { pts } \\
\text { Present }-2 \text { pts }\end{array}$ \\
\hline Q3 & $\begin{array}{l}\text { Presence of exclusion } \\
\text { criteria }\end{array}$ & $\begin{array}{l}\text { None }-0 \text { pts } \\
\text { Present }-2 \text { pts }\end{array}$ \\
\hline Q4 & $\begin{array}{l}\text { Presence of inclusion } \\
\text { criteria }\end{array}$ & $\begin{array}{l}\text { None }-0 \text { pts } \\
\text { Present }-2 \text { pts }\end{array}$ \\
\hline 05 & $\begin{array}{l}\text { Standard bruxism } \\
\text { assessment }\end{array}$ & $\begin{array}{l}\text { Other }-0 \text { pts } \\
\text { Parent interview/questionnaire }-1 \mathrm{pt} \\
\text { Physical examination, history taken } \\
\text { according to AASM guidelines - } 2 \text { pts }\end{array}$ \\
\hline Q6 & Headache assessment & $\begin{array}{l}\text { No information }-0 \text { pts } \\
\text { Questionnaire }-1 \mathrm{pt} \\
\text { Clinical tests performed by a specialist } \\
\text { doctor }-2 \text { pts }\end{array}$ \\
\hline Q7 & Conflict of interest & $\begin{array}{l}\text { Present }-0 \text { pts } \\
\text { No information }-1 \mathrm{pt} \\
\text { None }-2 \mathrm{pts}\end{array}$ \\
\hline Q8 & $\begin{array}{l}\text { Local ethics committee } \\
\text { approval }\end{array}$ & $\begin{array}{l}\text { No information }-0 \text { pts } \\
\text { Present }-2 \text { pts }\end{array}$ \\
\hline \multicolumn{3}{|c|}{ 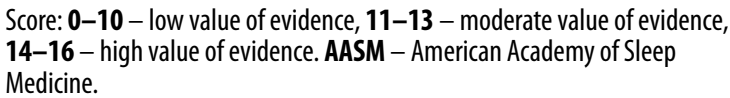 } \\
\hline
\end{tabular}

Tab. 2. Questions and scores for the analysed studies

A study on adults by Fernandes et al. demonstrated that bruxism significantly increases the risk of migraine episodes, episodic tension-type headache and chronic migraine in particular ${ }^{(12)}$. This is consistent with the results obtained by both Bortoletto et al. ${ }^{(9)}$ and Masuko et al. ${ }^{(10)}$. A literature review conducted in 2014 by De Luca Canto et al. produced the opposite findings to those of the studies assessed and mentioned in this paper ${ }^{(13)}$. The authors of that review find that there is not enough evidence to support or refute an association between tension-type headache and migraine, and sleep bruxism in children ${ }^{(13)}$. Similar conclusions were presented by Porporatti et al., who studied 400 adults and did not find any link between the presence of bruxism and primary headaches ${ }^{(14)}$.

However, Das et al. state that sleep bruxism may cause headaches ${ }^{(3)}$. Kato et al. also noticed a correlation between bruxism and primary headaches in the form of migraine ${ }^{(15)}$. The results obtained by Das et al. and Kato et al. are consistent with those of Bortoletto et al. ${ }^{(9)}$ and Masuko et al. ${ }^{(10)}$, which are discussed in this review.

It is worth emphasising the fact that in no study discussed in this paper were children the majority of patients in whom the influence of bruxism on primary headaches was investigated. Nearly the whole literature on the subject focuses on adults. Despite the consistency between the results of publications discussed in this paper we can assume that there is too little evidence to support the hypothesis that sleep bruxism affects the risk of primary headaches in children. Further research is needed on this problem, which may contribute to faster and more effective diagnosis of bruxism and primary headaches in children, and, consequently, more effective therapy of paediatric patients.

\section{CONCLUSIONS}

Considering the value of evidence and the size of study groups in the analysed research projects, the link between bruxism and primary headaches in children cannot be confirmed. Further research is necessary regarding the relationship between bruxism and primary headaches in children.

\section{Conflict of interest}

The authors do not report any financial or personal affiliations to persons or organisations that could adversely affect the content of or claim to have rights to this publication.

\begin{tabular}{|c|c|c|c|c|c|c|c|c|c|c|}
\hline \multirow{2}{*}{ First author } & \multirow{2}{*}{ Title } & \multicolumn{8}{|c|}{ Score } & \multirow{2}{*}{ Results } \\
\hline & & Q1 & Q2 & Q3 & Q4 & Q5 & Q6 & Q7 & Q8 & \\
\hline Bortoletto CC & The relationship between bruxism, sleep quality, and headaches in schoolchildren & 2 & 2 & 2 & 0 & 2 & 0 & 2 & 2 & 12 \\
\hline Masuko AH & Prevalence of bruxism in children with episodic migraine - a case-control study with polysomnography & 1 & 2 & 0 & 2 & 2 & 2 & 2 & 2 & 13 \\
\hline
\end{tabular}

Tab. 3. Evaluation of the analysed studies 


\section{References}

1. Piech P, Sudzińska H, Pietrak J et al.: Botulinum toxin in bruxism treatment. J Educ Health Sport 2017; 7: 398-411.

2. Lobbezoo F, Ahlberg J, Glaros AG et al.: Bruxism defined and graded: an international consensus. J Oral Rehabil 2013; 40: 2-4.

3. Das S, Gupta R, Dhyani M et al.: Headache secondary to sleeprelated bruxism: a case with polysomnographic findings. J Neurosci Rural Pract 2015; 6: 248-251.

4. Cuvellier JC, Donnet A, Guégan-Massardier É et al.: Treatment of primary headache in children: a multicenter hospital-based study in France. J Headache Pain 2009; 10: 447-453.

5. Lateef TM, Merikangas KR, He J et al.: Headache in a national sample of American children: prevalence and comorbidity. J Child Neurol 2009; 24: 536-543.

6. Talebian A, Soltani B, Haji Rezaei M: Causes and associated factors of headaches among 5 to 15 -year-old children referred to a Neurology Clinic in Kashan, Iran. Iran J Child Neurol 2015; 9: 71-75.

7. Lewis DW: Headaches in children and adolescents. Am Fam Physician 2002; 65: 625-633.

8. Abu-Arafeh I, Razak S, Sivaraman B et al.: Prevalence of headache and migraine in children and adolescents: a systematic review of population-based studies. Dev Med Child Neurol 2010; 52: 1088-1097.
9. Bortoletto CC, Salgueiro M da CC, Valio R et al.: The relationship between bruxism, sleep quality, and headaches in schoolchildren. J Phys Ther Sci 2017; 29: 1889-1892.

10. Masuko AH, Villa TR, Pradella-Hallinan $M$ et al.: Prevalence of bruxism in children with episodic migraine - a case-control study with polysomnography. BMC Res Notes 2014; 7: 298.

11. van der Meer HA, Speksnijder CM, Engelbert RHH et al.: The association between headaches and temporomandibular disorders is confounded by bruxism and somatic symptoms. Clin J Pain 2017; 33: 835-843.

12. Fernandes G, Franco AL, Gonçalves DA et al.: Temporomandibular disorders, sleep bruxism, and primary headaches are mutually associated. J Orofac Pain 2013; 27: 14-20.

13. De Luca Canto G, Singh V, Bigal ME et al.: Association between tension-type headache and migraine with sleep bruxism: a systematic review. Headache 2014; 54: 1460-1469.

14. Porporatti AL, Costa YM, Conti PCR et al.: Primary headaches interfere with the efficacy of temporomandibular disorders management. J Appl Oral Sci 2015; 23: 129-134.

15. Kato M, Saruta J, Takeuchi M et al.: EHMTI-0089. Relationship of sleep bruxism and migraine. J Headache Pain 2014; 15 Suppl 1: D32. 